\title{
ANALISIS YURIDIS PENYELESAIAN SENGKETA HIBAH DI PENGADILAN TINGGI MEDAN (Studi Kasus Putusan No.142/PDT/2015/PTMDN)
}

\author{
Oleh: \\ Ria Sintha Devi ${ }^{1)}$ \\ Alusianto Hamonangan ${ }^{2)}$ \\ Emi Rafika Sitepu ${ }^{3)}$ \\ Universitas Darma Agung, Medan. ${ }^{1,2,3)}$ \\ E-mail:

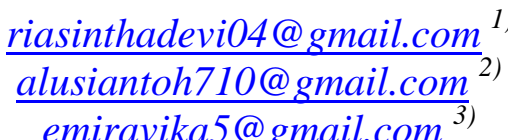

\begin{abstract}
ABSTRAK
This gift is regulated in article 1882 of the Civil Code which states, among other things, that the gift must be made with a notary deed, especially for immovable property, while for movable property it can be granted just like that, a gift made outside of it is canceled. Likewise, a grant cannot be renewed, even if it is made with a notary deed, which means that updates on the grant or by making changes or additions from the time the grant was originally made are not allowed. Regarding the reasons for the cancellation of the grant, the cancellation of this grant is regulated by Article 1666 of the Civil Code, which states that a grant cannot be withdrawn or canceled because of it. The problems that will be investigated are: How do you prove the validity of a grant deed in the Case Study of Decision No. 142 / PDT / 2015 / PT.Mdn?, Why can't a grant be withdrawn but can be canceled? decide the case No. 142 / PDT / 2015 / PT-MDN ?. This study uses a normative legal approach. Normative legal research in this research is carried out on the procedure for settlement of grant disputes through courts. The type of data used in this legal research is secondary data. Secondary data sources in this legal research were obtained from: Primary legal materials, among others: Civil Code, Law No. 48/2009 concerning Judicial Power, Decision No.142 / PDT / 2015 / PTMDN. In proving the validity of a Grant Deed, it must have physical, formal and material evidentiary strength, and the process of making a Grant Deed meets the elements stipulated by Article 1868 of the Civil Code. Basically, a grant is irrevocable but can be canceled based on exceptions that have been determined based on statutory regulations. The Legal Considerations of the Medan High Court Judge against the Simalungun District Court Decision No.55 / Pdt.G / 2014 / PN-Sim regarding the settlement of grant disputes in this case were declared incorrect and wrong because the appellate's memory of appeal is very reasonable based on law and can prove that the object of the dispute is the right of the appellant whose truth cannot be denied by the party being appealed against in the counter memorandum of appeal.
\end{abstract}

Keywords: Disputes, Grants, Medan High Court

\section{ABSTRAK}

Hibah ini diatur dalam pasal 1882 KUH Perdata yang menyatakan antara lain bahwa hibah harus dilakukan dengan akta notaris, terutama untuk barang tidak bergerak, sedangkan untuk barang bergerak dapat diberikan begitu saja, 
pemberian dilakukan di luar. dari itu dibatalkan. Demikian pula, hibah tidak dapat diperpanjang, meskipun dibuat dengan akta notaris, yang berarti bahwa pembaruan atas hibah atau dengan melakukan perubahan atau penambahan dari saat hibah dibuat tidak diperbolehkan. Mengenai alasan pembatalan hibah, pembatalan hibah ini diatur dalam Pasal 1666 KUH Perdata yang menyatakan bahwa hibah tidak dapat ditarik kembali atau dibatalkan karenanya. Permasalahan yang akan diteliti adalah: Bagaimana cara membuktikan keabsahan akta hibah dalam Studi Kasus Putusan Nomor 142 / PDT / 2015 / PT.Mdn ?, mengapa hibah tidak dapat ditarik tetapi dapat dibatalkan? memutus perkara No. 142 / PDT / 2015 / PT-MDN?. Penelitian ini menggunakan pendekatan hukum normatif. Penelitian hukum normatif dalam penelitian ini dilakukan terhadap tata cara penyelesaian sengketa hibah melalui pengadilan. Jenis data yang digunakan dalam penelitian hukum ini adalah data sekunder. Sumber data sekunder dalam penelitian hukum ini diperoleh dari: Bahan hukum primer antara lain: KUH Perdata, UU No. 48/2009 tentang Kekuasaan Kehakiman, Putusan No.142 / PDT / 2015 / PTMDN. Dalam pembuktian keabsahan Akta Hibah harus memiliki kekuatan pembuktian fisik, formal dan material, dan proses pembuatan Akta Hibah memenuhi unsur-unsur yang diatur dalam Pasal 1868 KUH Perdata. Pada dasarnya, hibah tidak dapat dibatalkan tetapi dapat dibatalkan berdasarkan pengecualian yang telah ditentukan berdasarkan peraturan perundang-undangan. Pertimbangan Hukum Hakim Pengadilan Tinggi Medan terhadap Putusan Pengadilan Negeri Simalungun No.55 / Pdt.G / 2014 / PN-Sim tentang penyelesaian sengketa hibah dalam perkara ini dinyatakan tidak benar dan salah karena memori kasasi dari Banding sangat tinggi. wajar berdasarkan hukum dan dapat membuktikan bahwa objek sengketa adalah hak pemohon banding yang kebenarannya tidak dapat disangkal oleh pihak yang dimohonkan dalam kontra memori banding.

Kata Kunci: Sengketa, Hibah, Pengadilan Tinggi Medan

\section{PENDAHULUAN}

Perkataan hibah atau memberikan sesuatu kepada orang sebagai perbuatan hukum itu dikenal baik di dalam masyarakat Hukum Adat, Hukum Islam maupun di dalam Burgerlikj Wetboek. Hibah dilakukan sewaktu pemberi hibah masih hidup, dan harus diberikan secara cuma-cuma. Hal ini dirumuskan dalam pasal 1666 BW yang menyatakan bahwa, hibah adalah suatu persetujuan dimana sipenghibah diwaktu hidupnya, dengan cuma-cuma dan dengan tidak dapat ditarik kembali, menyerahkan sesuatu guna keperluan si penerima hibah yang menerima penyerahan itu.
Hal ini harus dibedakan dengan hibah wasiat. Di dalam masyarakat Hukum Adat, hibah ini dilakukan sewaktu anak-anaknya sudah menikah dan dipisahkan denga nmembuatkan rumah, memberikan perkarangan untuk pertanian, ini harus dibedakan dengan weling (jawa) yang bersifat semacam wasiat. Yaitu sebelum seorang meninggal, maka ia akan mengadakan ketetapan-ketetapan yang ditujukan kepada ahli warisnya atau istrinya. Pertama, ia semasa hidupnya memberi petunjuk-petunjuk bagaimana harta bendanya akan dibagi waris kalau ia meninggal. Jadi barang-barangnya itu belum dibagi-bagikannya kepada ahli warisnya, melainkan masih 
dipegangnya, hanya kalau ia meninggal maka pembagian harta peninggalannya harus dilakukan menurut petunjukpetunjuk tersebut. Pada prinsipnya setiap orang dapat menjadi subyek persetujuan hibah kecuali:

1. Anak-anak dibawah umur mereka tidak kuasa memberi hibah. Mereka dilarang membuat persetujuan hibah atas sesuatu barang apapun. Hibah yang mereka perbuat dapat diminta pembatalannya (vernietigbaar). Cuma bukan batal dengan sendirinya;

2. Antar suami istri tidak boleh menjadi subyek persetujuan hibah. Karena itu pemberian hibah antara suami istri yang terikat dalam perkawinan adalah terlarang. Maksud pelarangan ini jelas, untuk melindungi pihak ketiga yang mempunyai tagihan kepada salah seorang suami istri tersebut.

Maka dengan adanya hibah itu sendiri, sipenerima hibah bukan saja dapat menikmati hasilnya saja akan tetapi dengan hak dan kewajiban di bidang hukum, bahwa janji yang diminta si penghibah untuk tetap berkuasa menjual atau memberikan barangnya kepada orang lain, berarti bahwa hak milik atas barang tersebut tetap ada padanya karena hanya seorang pemilik dapat menjual atau memberikan barangnya kepada orang lain hal mana dengan sendirinya bertentangan dengan sifat dan penghibahan sudah jelas bahwa janji seperti itu membuat penghibahan batal, apalagi yang terjadi hanyalah suatu pemberian hak nikmat saja. Berdasarkan uraian diatas maka penulis tertarik untuk melakukan penelitian dengan judul "Analisis Yuridis Penyelesaian Sengketa Hibah di Pengadilan Tinggi Medan (Studi Kasus Putusan

No.142/PDT/2015/PTMDN)".

\section{TINJAUAN PUSTAKA}

Undang-undang telah menetapkan cara penghibahan ini.Penghibahan ini diatur dalam pasal 1882 KUH Perdata yang menyabutkan antara lain,bahwa penghibahan itu harus dilakukan dengan akta notaris terutama untuk barang tak bergerak, sedangkan untuk barang bergerak dapat dihibahkan begitu saja maka suatu penghibahan yang dilakukan di luar ituadalah batal. Akta notaris ini merupakan suatu syarat mutlak dari sahnya suatu hibah, dengan sendirinya kalau hibah dibuat dengan cara dibawah tangan adalah batal. Demikian juga hibah itu tidak dapat dibuat suatu pembaharuan, biarpun hal ini dibuat dengan akta notaris yang artinya bahwa pembaharuan tentang hibah atau dengan mengadakan perubahan atau penambahan sejak semula hibah itu dibuat tidak diperbolehkan.

Mengenai alasan-alasan pembatalan hibah pembatalan hibah ini diatur Pasal 1666 KUH Perdata, yang menyebutkan bahwa suatu hibah tidak dapat ditarik kembali maupun dihapuskan karenanya, melainkan dalam hal-hal berikut:

1. Karena tidak dipenuhi syarat-syarat dimana penghibahan telah dilakukan;

2. Jika sipenerima hibah telah bersalah melakukan atau membantu melakukan kejahatan yang bertujuan mengambil jiwa si penghibah atau suatu kejahatan lain terhadap si penghibah;

3. Jika ia menolak memberikan tunjangan nafkah kepada sipenghibah, setelahnya orang ini jatuh dalam kemiskinan.

Dalam kenyataannya di Pengadilan Tinggi Medan No.142/PDT/2015 PT MDN.Tanggal 23 April 2015 terdapat putusan perkara yang tidak sesuai dengan buku III Bab X (Pasal 1666-1693)KUH Perdata, 
dimana Hakim dalam penjatuhan putusan terhadap penghibahan akta tanah yang disengketakan.

\section{METODE PELAKSANAAN}

Penelitian ini menggunakan pendekatan hukum normatif yang mengidentifikasi dan mengkonsepsi hukum sebagai norma kaidah, peraturan, Undang-Undang yang berlaku pada suatu waktu dan tempat tertentu sebagai produk dari suatu kekuasaan yang berdaulat. Penelitian hukum normatif dalam penelitian ini dilaksanakan terhadap prosedur penyelesaian sengketa hibah melalui pengadilan.Tujuannya adalah untuk meneliti asas-asas hukum yang digunakan dalam penyelesaian sengketa hibah. Jenis data yang digunakan dalam penelitian hukum ini adalah data sekunder. Sumber data sekunder dalam penelitian hukum ini diperoleh dari : Bahan-bahan hukum primer adalah sumber hukum yang berlakunnya bersifat mengikat, antara lain: KUH Perdata, Undang-Undang No 48 Tahun 2009 Tentang Kekuasaan Kehakiman, Putusan No.142/PDT/2015/PTMDN. Bahan hukum sekunder berupa berbagai buku hasil karya para pakar, hasil-hasil penelitian dan kegiatan ilmiah lainnya. Bahan hukum tersier yakni bahan yang memberikan penjelasan terhadap bahan hukum primer dan sekunder berupa kamus hukum, ensiklopedia dan sebagainnya.

\section{HASIL DAN PEMBAHASAN}

\section{Cara Membuktikan Suatu Keabsahan Akta Hibah Dalam Studi Kasus Putusan No.142/PDT/2015/PT.Mdn}

Dalam studi kasus putusan no.142/PDT/2015/PT.Mdn, berdasarkan pendapat Majelis Hakim Pengadilan
Tinggi bahwa Akta Hibah No.32/1976 tanggal 29 Maret 1976 yang dibuat oleh M.Y.Panjaitan dengan G.Sitorus di hadapan H.Z.Sinaga selaku Camat Kecamatan Bandar, Kabupaten Simalungun yang bertindak sebagai Pejabat Pembuat Akta Tanah adalah "sah menurut hukum" karena Akta Hibah tersebut adalah akta otentik yang dibuat dalam bentuk yang ditentukan oleh Undang-Undang oleh atau di hadapan Pejabat umum yang berwenang yaitu dibuat oleh Camat selaku Pejabat Pembuat Akta Tanah (PPAT) telah sesuai dengan Pasal 1868 KUH Perdata : "Suatu akta otentik ialah suatu akta yang dibuat dalam bentuk yang ditentukan Undang-Undang oleh atau di hadapan pegawai-pegawai umum yang berkuasa untuk itu, di tempat dimana akta itu dibuat". Dengan demikian dalam Studi Kasus Putusan No.142/PDT/2015/PT.Mdn Majelis Hakim sudah menetapkan bahwa Akta Hibah No.32/1976 yang merupakan objek sengketa adalah sah menurut hukum milik G.Sitorus yang telah dihibahkan M.Y.Panjaitan di hadapan H.Z.Sinaga selaku Camat Kecamatan Bandar Kabupaten Simalungun. Dan menetapkan Daud Sitorus (penggugat) sah secara hukum seorang ahli waris dari Almarhum G.Sitorus berdasarkan Surat Keterangan Ahli Waris No.2232/SK-AW/VI/2014.

Dalam sebuah akta otentik harus memenuhi kekuatan pembuktian lahiriah, formil dan materil. Kekuatan pembuktian lahiriah didasarkan atas keadaan lahiriah, apa yang tampak pada lahirnya, yaitu surat yang tampak seperti akta dianggap mempunyai kekuatan seperti akta sepanjang tidak dibuktikan sebaliknya. Maksud dari kata memiliki daya pembuktian lahiriah adalah melekatkan prinsip anggapan benar sebagai akta otentik sampai pihak 
yang membantah mampu membuktikan sebaliknya.

Sedangkan kekuatan pembuktian formil yang melekat pada akta otentik dijelaskan dalam Pasal 1871 KUH Perdata, bahwa segala keterangan yang tertuang di dalamnya adalah benar diberikan dan disampaikan penanda tangan kepada pejabat yang membuatnya. Oleh karena itu, segala keterangan yang diberikan penanda tangan dalam akta otentik, dianggap benar sebagai keterangan yang dituturkan dan yang dikehendaki yang bersangkutan. Anggapan atas kebenaran yang tercantum di dalamnya, bukan hanya terbatas pada keterangan atau pernyataan yang terdapat di dalamnya benar dari orang yang menandatanganinnya, tetapi juga meliputi kebenaran formil yang dicantumkan pejabat pembuat akta, antara lain :

1. Mengenai tanggal yang tertera di dalamnya;

2. Tanggal tersebut harus dianggap benar;

3. Berdasar kebenaran formil atas tanggal tersebut, tanggal pembuatan akta tidak dapat digugurkan lagi oleh para pihak dari Hakim.

Menurut A.A. Andi Prajitno, "kekuatan pembuktian formil merupakan pernyataan pejabat dalam tulisan yang tercantum dalam akta adalah sama dengan yang dilakukan dan disaksikan oleh pejabat yang bersangkutan dalam dalam menjalankan jabatannya, termasuk kepastian dari tanggal pembuatannya, tanda tangannya, dan tempat pembuatan aktanya".

Mengenai kekuatan pembuktian materil akta otentik menyangkut permasalahan benar atau tidak keterangan yang tercantum di dalamnya. Oleh karena itu, kekuatan pembuktian materil adalah persoalan pokok akta otentik karena memberi kepastian tentang materi suatu akta, memberi kepastian tentang peristiwa bahwa pejabat atau para pihak menyatakan dan melakukan seperti yang dimuat dalam akta. Dalam kekuatan pembuktian ini memberikan kepastian mengenai materi (isi) akta otentik, memberi kepastian mengenai perbuatan hukum atau peristiwa hukum yang dilakukan oleh pejabat pembuat akta atau para pihak dalam akta. Seperti penanda tangan akta otentik untuk keuntungan pihak lain, seseorang hanya dapat membebani kewajiban kepada diri sendiri dan akibat hukum akta yang dikaitkan dengan kekuatan pembuktian materil akta otentik.

Penanda tangan akta otentik untuk keuntungan pihak lain artinya setiap penanda tangan akta otentik oleh seseorang, selamannya harus dianggap untuk keuntungan pihak lain bukan untuk keuntungan pihak penanda tangan. Berdasarkan prinsip ini, apabila A menandatangani akta otentik yang berisi keterangan berhutang kepada $\mathrm{B}$ Rp 100 juta, berarti dengan akta itu A bermaksud memberi bukti kepada keuntungan $\mathrm{B}$ atas diri A sendiri, maka atas kebenaran materil yang melekat pada akta otentik itu, telah terbukti A berutang kepada B sebesar Rp 100 juta. Akan tetapi, berbeda halnya jika yang membuat dan menandatangani akta itu $B$ yang berisi keterangan atau pernyataan bahwa A berutang kepadannya (B) sebesar Rp 100 juta, maka akta itu tidak membuktikan sesuatu apapun karena keterangan yang tercantum dalam akta itu dibuat oleh seseorang (dalam hal ini $\mathrm{B}$ ) yang bertujuan merugikan diri orang lain (A) tanpa sepengetahuan A sendiri.

Seseorang hanya dapat membebani kewajiban kepada diri sendiri artinya siapa yang 
menandatangani akta otentik berarti dengan sukarela telah menyatakan maksud dan kehendak seperti yang tercantum di dalam akta untuk menjamin keterangan kebenaran keterangan tersebut, oleh karena itu di belakang hari penanda tangan tidak boleh mengatakan atau mengingkari bahwa dia tidak menulis atau memberi keterangan seperti yang tercantum dalam akta, namun demikian bukan berarti kebenaran itu bersifat mutlak sesuai keadaan sebenarnya. Kemungkinan saja isinnya palsu seperti dalam Putusan MA No.3783 K/Pdt/1987 yang dijelaskan di atas atau kemungkinan terhadapnya diajukan bukti lawan (tegen bewijs). Berdasarkan Pasal 1870KUH Perdata nilai kekuatan pembuktian yang melekat pada akta otentik adalah sempurna, akan tetapi hal itu sepanjang tidak ada bukti lawan. Oleh karena itu, kesempurnaanya tidak menentukan sehingga kekuatan pembuktian materilnya dapat dibuktikan oleh pihak lawan.

Akibat hukum akta yang dikaitkan dengan kekuatan pembuktian materil akta otentik maksudnya yaitu apabila terdapat dua orang atau lebih, dan antara yang satu dengan yang lain saling memberi keterangan atau pernyataan sepanjang saling bersesuaian sehingga melahirkan persetujuan yang mengikat kepada mereka yang dituangkan dalam bentuk akta, dengan demikian akta tersebut menjadi bukti tentang adannya persetujuan sebagaimana yang diterangkan dalam akta tersebut dan menimbulkan akibat hukum.

\section{Suatu Hibah Tidak Dapat Ditarik Kembali Tetapi Dapat Dibatalkan}

Pada prinsipnya suatu hibah tidak dapat ditarik kembali akan tetapi ada beberapa pengecualian dengan syarat yang diatur oleh Undang-Undang yaitu:

a. Pasal 1667 ayat (2) KUH Perdata: "jika hibah meliputi benda-benda yang baru akan ada di kemudian hari, maka hibahnya adalah batal" ;

b. Pasal 1668 KUH Perdata: "si penghibah tidak boleh memperjanjikan bahwa ia tetap berkuasa untuk menjual atau memberikan kepada orang lain suatu benda yang termasuk dalam hibah, hibah yang semacam itu, dianggap sebagai batal";

c. Pasal 1670 KUH Perdata: "suatu hibah adalah batal, jika dibuat dengan syarat bahwa si penerima hibah akan melunasi utang-utang atau beban-beban lain, selain yang dinyatakan dengan tegas di dalam akta hibah sendiri atau di dalam suatu daftar yang ditempelkan padanya";

d. Pasal 1682 KUH Perdata; "hibah atas benda tidak bergerak menjadi batal jika tidak dilakukan dengan akta notaris";

e. Pasal 1688 KUH Perdata ayat (1) : "tidak dipenuhi syarat-syarat dengan mana penghibahan dilakukan." Syarat umum dari suatu harta hibah adalah bahwa benda yang dihibahkan harus bebas dari hak orang lain/menjadi milik penuh dari si penghibah.

f. Pasal $1688 \mathrm{KUH}$ Perdata ayat (2) : “jika si penerima hibah telah bersalah melakukan atau ikut melakukan kejahatan untuk mengambil jiwa (membunuh) si pemberi hibah atau kejatan lain terhadap si penghibah." Suatu contoh dari suatu kejahatan lain (selain pembunuhan) terhadap si penghibah adalah penistaan.

g. Pasal 1688 KUH Perdata ayat (3) : "jika si penerima hibah menolak untuk memberi bantuan nafkah 
terhadap si penghibah, ketika si penghibah jatuh miskin.

Dalam Kompilasi Hukum Islam secara tegas disebutkan bahwa hibah tidak dapat ditarik kembali, kecuali penghibahan yang dilakukan orang tua kepada anaknya (Pasal 212 Kompilasi Hukum Islam). Penarikan kembali hibah setelah diserahkan hukumnya haram kecuali hibah seorang ayah kepada anaknya, diperbolehkan penarikan kembali hibah tersebut dikarenakan tidak ada tuduhan kepadadnya, karena secara tabiat seorang ayah akan selalu mendahulukan anaknya dan jika dia menarik kembali, maka berarti ada kebutuhan dan kemaslahatan. Dalam hal penarikan hibah Ulama Madhab Maliki mengatakan, pihak pemberi tidak mempunyai hak menarik kembali pemberiannya disebabkan hibah merupakan suatu akad yang tetap.

Dalam hadis Rasulullah Saw yang diriwayatkan oleh Bukhari dan Muslim:

"Orang yang kembali menarik haknya adalah seperti seekor anjing yang muntah-muntah kemudian ia makan muntahanya itu kembali".

"Tidak halal/tidak boleh salah

seorang kamu memberikan suatu pemberian kepada seseorang, kemudian dimintanya kembali, kecuali pemberian seorang ayah kepada anaknya".

Menyangkut hadis yang kedua harus dengan suatu syarat. Pengembalian tersebut adalah karena kasih sayang, cinta juga karena ia membutuhkannya dan memang tujuannya untuk mencari pahala akhirat. Jadi menurut Kompilasi Hukum Islam, apapun alasannya hibah tidak dapat ditarik kembali ataupun dibatalkan. Seperti halnya dalam sebuah perjanjian, pada dasarnya suatu perjanjian yang sudah dibuat atas kesepakatan bersama tidak lagi dapat dibatalkan, apalagi pembatalan yang dilakukan secara sepihak tanpa sepengetahuan pihak lain, meskipun demikian masih terdapat pengecualian.

Dalam masyarakat adat Jawa Barat terutama di desa Leuwi Liang dan Citeureup, suatu hibah dapat ditarik kembali apabila bertentangan dengan ketentuan-ketentuan Hukum Adat dan Hukum Islam.Sebaliknya di daerah Cianjur, Banjar, Ciamis, dan Cikenong suatu hibah tidak dapat ditarik kembali. Demikian pula di daerah Batujaya, Teluk Buyung, Pisang Sambo, Kecamatan Karawang dan Indramayu apabila hibah tersebut berupa hibah mutlak, maka hibah tersebut tidak dapat ditarik kembali. Dengan demikian maka dapat dikatakan pembatalan hibah menurut Hukum Adat ada beberapa daerah tertentu yang tidak dapat ditarik kembali dan ada yang dapat ditarik kembali apabila hibah tersebut tidak sesuai dengan ketentuan yang berlaku.

\section{Pertimbangan Hakim Pengadilan Tinggi Medan Dalam Memutus Perkara No.142 / PDT /2015 /PT- MDN.}

Pertimbangan Hakim berdasarkan Putusan Pengadilan Tinggi Medan Nomor 142 / PDT PDT / 2015 / PT-MDN bahwasannya Putusan Pengadilan Negeri Simalungun Nomor 55 / PDT.G /2014 /PN-SIM bertentangan dengan Pasal-Pasal yang bersangkutan: Kitab Undang-Undang Hukum Perdata dan Kitab UndangUndang Acara Perdata serta peraturan hukum lainnya.

Menimbang bahwa yang menjadi gugatan pokok dalam gugatan ini adalah tentang "hibah" atas sebidang tanah, yang berdasarkan berdasarkan Berita Acara Pemeriksaan setempat yang dilakukan oleh Pengadilan Negeri Simalungun pada tanggal 30 Januari 
2015, tanah tersebut terletak di Lingkungan Kuala Tanjung, Kelurahan Perdagangan III, dahulu Perdagangan I Kecamatan Bandar, Kabupaten Simalungun, yang batas-batas dan ukurannya adalah :

1. Sebelah Timur : dahulu disebut Jalan Gereja HKBP sekarang disebut Jalan Kartini, panjang 96 meter;

2. Sebelah Barat: dengan pekarangan kilang padi Lambang, panjang 100 meter;

3. Sebelah Utara dengan tanah M.R Simanjuntak lebar26,5 meter;

4. Sebelah Selatan : dahulu Jalan Bahlias sekarang disebut Jalan Kuala Tanjung lebar 19 meter.

Dihibahkan

oleh

M.Y.Panjaitan kepada G.Sitorus di hadapan H.Z. Sinaga Camat Kecamatan Bandar Kabupaten Simalungun yang bertindak sebagai Pejabat Pembuat Akta Tanah, sebagaimana tersebut dalam Akta Hibah Nomor 32/1976 tanggal 29 Maret 1976.Menimbang bahwa berdasarkan Bukti P-2 (Akta Hibah No.32/1976 tanggal 29 Maret 1976), pada tanggal 29 Maret 1976 M.Y. Panjaitan telah menghibahkan tanahnya seluas 2217 meter persegi yang terletak Daerah Tingkat I Sumatera Utara, Daerah Tingkat II Simalungun, Kecamatan Bandar, Desa Perdagangan I kepada G.Sitorus disaksikan oleh M.K. Saragih.

Menimbang bahwa Pasal 1 Akta Hibah No.32/1976 tanggal 29 Maret 1976 (Bukti P-2) menyebutkan : "Mulai hari ini tanah yang diuraikan dalam Akta ini telah diserahkan kepada yang menerima hibah, yang mengaku pula telah menerima penyerahan itu, dan segala keuntungan yang didapat serta segala kerugian/ beban yang diderita atas tanah dan bangunannya tersebut di atas menjadi hak / tanggungan yang menerima hibah. Menimbang bahwa
Pasal 2 Akta Hibah No.32/1976 tanggal

29 Maret $1976 \quad$ (Bukti P-2) menyebutkan : "Selama hidupnnya yang menghibahkan, dan selama itu tidak boleh dialihkan kepada pihak lain tanpa seizin yang menghibahkan. Menimbang bahwa Penggugat adalah ahliwaris dari: Almarhum Gulontam Sitorus yang meninggal dunia pada tanggal 3 Oktober 1998, dan Almarhumah Salbilah Siagian yang meninggal dunia pada tanggal 25 Januari 2011 sebagaimana tersebut dalam Surat Keterangan Ahli waris, (Bukti P.1). Menimbang bahwa Tergugat I adalah ahliwaris dari : Alm. M.Yusuf Panjaitan yang telah meninggal pada tanggal 18 September 2009 sebagaimana tersebut dalam Surat Pernyataan Ahli waris, (Bukti T.I, II, III, IV, V-1).

Menimbang bahwa Tergugat: I, II, II, IV, V dalam jawabannya maupun di dalam kontra memori bandingnya mendalilkan yang pada pokoknya bahwa Akta Hibah No.32/1976 tanggal 29 Maret 1976 tersebut telah ditarik / dibatalkan oleh M.Y. Panjaitan atas kesepakatan M.Y. Panjaitan dengan G.Sitorus pada tanggal 23 Mei 1986 yang ditandatangani oleh M.Y.Panjaitan dengan Gulontam Sitorus(G.Sitorus) dan saksi-saksi ; vide surat Penarikan Hibah, (Bukti T.I, II, III, V, V-8), bahwa dalam Surat Penarikan Hibah, (BuktiT. I, II, III, V, V-8) tersebut dinyatakan : "M.Y. Panjaitan membatalkan Surat Hibah ( Akta Hibah Nomor 32/1976), G. Sitorus harus meninggalkan tanah tersebut selambatlambatnnya satu bulan setelah kesepakatan ini dan harus mengembalikan perjanjian hibah Nomor 32/1976 yang diakui G.Sitorus tercecer belum ditemukan”.

Menimbang bahwa

Penggugat membantah (Bukti T. I, II, 
III, IV, V-8) tersebut dalam repliknya dan menyatakan pada pokoknya bahwa M.Y.Panjaitan tidak pernah membatalkan Akta Hibah tersebut sampai M.Y.Panjaitan meninggal pada tanggal 18 September 2009, akan tetapi pada tahun 1995 Tergugat I telah berupaya dengan berbagai cara disertai anacaman kekerasan berusaha mengusir paksa G.Sitorus (orang tua Penggugat) dari tanah terperkara, dan atas pertimbangan keluarga serta untuk keselamatan jiwa G.Sitorus pada waktu itu dengan terpaksa G.Sitorus pindah dari tanah terperkara. Sejak itu Tergugat I selalu berusaha untuk menjual tanah terperkara akan tetapi selalu gagal karena Tergugat I tidak dapat menunjukkan bukti surat kepemilikan atas tanah terperkara, kemudian surat pembatalan akta hibah muncul secara tiba-tiba pada waktu Lurah Perdagangan III dijabat oleh Tergugat VIII, Penggugat yakin bahwa Surat Pembatalan Hibah tanggal 23 Mei 1986 adalah palsu karena orang tua Penggugat tidak pernah menandatangani Surat Pembatalan hibah tersebut. Terlepas dari benar tidaknya penarikan hibah tersebut, maka penarikan tersebut tidak sah sebagaimana dalam Pasal 1666 ayat (1) KUH Perdata dikarenakan Majelis Hakim Pengadilan Tinggi berpendapat bahwa tanah sengketa dalam perkara ini telah dihibahkan oleh pemberi hibah M.Y. Panjaitan kepada penerima hibah G.Sitorus atau ahli waris penerima hibah G.Sitorus sedangkan seluruh ahli waris pemberi hibah M.Y.Panjaitan termasuk Tergugat I dan Tergugat II ama sekali tidak berhak lagi atas tanah tersebut.

Menimbang bahwa dari ketentuan Pasal 1666 ayat (1) tersebut Majelis Hakim Pengadilan Tinggi berpendapat bahwa penghibahan adalah suatu perikatan (persetujuan) antara pemberi hibah dengan penerima hibah, dengan mana seorang penghibah menyerahkan suatu barang secara cumacuma, tanpa dapat menariknya kembali dan untuk kepentingan seseorang yang menerima penyerahan barang itu.

Menimbang bahwa dalam Pasal 1668 KUH Perdata ditentukan: Penghibah tidak boleh menjanjikan bahwa ia tetap berkuasa untuk menggunakan hak miliknnya atas barang yang dihibahkan itu, penghibahan itu hanya terkait dengan barang tersebut dan dianggap tidak sah. Majelis Hakim Pengadilan Tinggi berpendapat bahwa jika penghibah tetap berkuasa untuk menggunakan hak miliknya atas barang yang dihibahkannya itu berarti tidak pernah ada penghibahan atas barang miliknya tersebut, karena tidak ada manfaatnya kepada penerima hibah.

Menimbang bahwa dalam Akta Hibah No.32 / 1976 tanggal 29 Maret 1976 (Bukti P-2), M.Y.Panjaitan telah menyerahkan tanah seluas 2217 M2 (2217 meter persegi) kepada G.Sitorus pada tanggal 29 Maret 1976 dengan klausula pada Pasal 2 Akta Hibah itu disebutkan : "Selama hidupnya yang menghibahkan tanah tersebut di atas tetap dipergunakan oleh yang menghibahkan dan selama itu tidak boleh dialihkan kepada pihak lain tanpa seizin yang menghibahkan". Dengan adanya kalusula pada Pasal 2 tersebut Majelis Hakim Pengadilan Tinggi berpendapat bahwa hibah M.Y. Panjaitan kepada G.Sitorus merupakan penghibahan bersyarat seperti halnya perjanjian bersyarat berdasarkan ketetapan waktu yaitu penghibah (M.Y. Panjaitan) bebas menggunakan tanah yang dihibahkannya kepada G.Sitorus selama hidupnya. 
Menimbang bahwa Akta Hibah No.32/1976 tanggal 29 Maret 1976 tersebut adalah berbeda dengan ketentuan Pasal 1668 KUH Perdata karena Pasal tersebut sama sekali tidak memberikan kesempatan kepada penerima hibah untuk menguasai barang yang dihibahkan, sedangkan pada Akta Hibah No.32/1976 tanggal 29 Maret tersebut merupakan perjanjian bersyarat bahwa penerima hibah dapat menguasai sepenuhnya barang yang dihibahkan kepadannya setelah penghibah meninggal dunia, berdasarkan isi Akta Hibah tersebut Majelis Hakim.

Menimbang bahwa Akta Hibah No.32/1976 tanggal 29 Maret 1976 tersebut adalah akta otentik karena dibuat dalam bentuk yang ditentukan oleh Undang-Undang oleh atau di hadapan pejabat umum yang berwenang yaitu dibuat oleh Camat selaku Pejabat Pembuat Akta Tanah (PPAT), berdasarkan pertimbangan tersebut Majelis Hakim Pengadilan Tinggi tidak sependapat dengan pertimbangan Majelis Hakim Pengadilan Negeri dan Majelis Hakim Pengadilan Tinggi berpendapat bahwa Akta Hibah No.32/1976 tanggal 29 Maret 1976 yang dibuat oleh M.Y. Panjaitan dengan G.Sitorus di hadapan H.Z.Sinaga selaku Camat Kecamatan Bandar, Kabupaten Simalungun yang bertindak sebagai Pejabat Pembuat Akta Tanah (Bukti P2) adalah " sah menurut hukum", dan berdasarkan pertimbangan tersebut tuntutan Penggugat pada petitum nomor dua pada gugatan tersebut dapat dikabulkan.

Menimbang bahwa penggugat mendalilkan yang pada pokoknya bahwa Lurah Perdagangan III (Tergugat VIII) pernah mengundang penggugat dengan tergugat I tentang keberadaan surat tanah terperkara atas undangan tersebut penggugat dan tergugat I menghadirinya dan penggugat menunjukkan bukti kepemilikan atas tanah terperkara yaitu Akta Hibah No.32/1976 serta bukti Pembayaran Pajak Bumi dan Bangunan (PBB) yang sampai sekarang masih tetap dibayar penggugat atas nama $G$ Sitorus sedangkan tergugat I pada waktu itu tidak dapat menunjukkan alasan hak kepemilikannya atas tanah terperkara dan pada waktu pertemuan tersebut penggugat mengingatkan tergugat VIII agar tidak menerbitkan sesuatu surat berbentuk apapun apabila ada yang mengaku-ngaku sebagai pemilik tanah terperkara termasuk kepada tergugat I. Tergugat VIII sebagai Lurah Perdagangan III dalam jawabannya bahwa berdasarkan Peraturan Daerah Kabupaten Simalungun Nomor 4 Tahun 2008 tentang Pembentukan Kelurahan Perdagangan III,Kecamatan Bandar pada Pasal 7 ayat (2) huruf $\mathrm{g}$ menyatakan: "Lurah mempunyai tugas melaksanakan urusan penyelesaian perselisihan, persengketaan dan permasalahan tanah".

Menimbang bahwa pada tanggal 22 Desember 2010 tergugat I melaporkan ke Polisi bahwa tergugat I telah kehilangan satu lembar Surat Keterangan Tanah seluas 2187 M2 dengan Nomor: 387/SKT.8/2000 yang terletak di Jalan Kuala Tanjung Kelurahan Perdagangan III A.N.M.Yoesoef Panjaitan (Bukti T.VIII1, T.VIII-2, T.VIII-3) kemudian tergugat VIII menerbitkan Surat Keterangan Tanah Nomor.593/084/2011 berdasarkan Surat Tanda Penerimaan Laporan Kehilangan Barang Nomot: STPLKB/654/XII/2010/tanggal 22 Desember 2010 yang dikeluarkan oleh Kepala Kepolisian Sektor Perdagangan karena tergugat VIII menerbitkan Surat Keterangan Tanah tersebut atas dasar 
surat laporan kehilangan tersebut tanpa didukung oleh bukti-bukti kepemilikan yang sah, maka Surat Keterangan Tanah yang diterbitkannya itu tidak mempunyai nilai kekuatan hukum, Maka Majelis Hakim berpendapat bahwa perbuatan tergugat VIII mengeluarkan surat keterangan tanah tersebut "bukan perbuatan melawan hukum", walaupun Surat Keterangan Tanah yang diterbitkannya itu tidak mempunyai kekuatan hukum. Oleh karena itu, Tuntutan penggugat agar tergugat VIII dinyatakan telah melakukan perbuatan melawan hukum harus ditolak.

Menimbang bahwa tergugat I dan tergugat II telah menjual tanah yang dihibahkan tersebut (telah disengketakan) kepada tergugat III di hadapan tergugat VI (RACHMANSYAH PURBA, S.H., M.Kn., Notaris) sebagaimana tersebut dalam bukti T. I,II,III,IV,V-6, padahal tergugat I dan tergugat II maupun seluruh ahliwaris M.Y.Panjaitan tidak berhak lagi atas tanah tersebut, maka perbuatan tergugat I dan tergugat II telah menjual tanah yang telah dihibahkan kepada tergugat III adalah "perbuatan melawan hukum" dan jual beli tanahtersebut dari tergugat I dan tergugat II kepada tergugat III tidak mempunyai kekuatan hukum yang mengikat dan tidak menimbulkan akibat hukum, selanjutnya tergugat III menjual tanah tersebut kepada tergugat $\mathrm{V}$ (ONGKO INDRAWAN) melalui tergugat IV di hadapan tergugat VII (GUNAWAN TARIGAN, S,H., Pekerjaan Notaris). Karena tergugat IV hanya menjalankan kuasa yang diberikan oleh tergugat III untuk menjual tanah terperkara maka tergugat IV tidak dapat dikategorikan melakukan perbuatan melawan hukum.
Menimbang bahwa karena tergugat III maupun tergugat $\mathrm{V}$ membeli tanah terperkara melalui pejabat yang berwenang dan pejabat tersebut telah melakukan pekerjaanya sesuai dengan ketentuan dan kewenangannya, maka perbuatan tergugat III dan tergugat $\mathrm{V}$ maupun tergugat VI dan tergugat VII selaku pejabat yang berwenang dalam transaksi tersebut tidak termasuk melakukan perbuatan melawan hukum meskipun perbuatan yang dilakukannya itu secara hukum tidak sah, sehingga tidak menimbulkan akibat hukum dan tidak mempunyai kekuatan hukum yang mengikat.

Menimbang bahwa karena Akta Pelepasan Hak dengan Ganti Rugi No.42 tanggal 28 Juni 2012 atas tanah terperkara antara tergugat I dan tergugat II dengan tergugat III yang dibuat dihadapan tergugat VI dan Akta Pelepasan Hak Atas Tanah dan Ganti Rugi No.3 tanggal 12 November 2013 antara tergugat III dengan tergugat $\mathrm{V}$ melalui tergugat IV dihadapan tergugat VII tanpa dasar hukum yang sah, maka Akta tersebut dengan sendirinya tidak mempunyai kekuatan hukum yang mengikat.

Menimbang bahwa karena Akta Hibah No.32/1976 tanggal 29 Maret 1976 tersebut sah menurut hukum, sedangkan penarikan akta hibah itu tidak sah karena tidak berdasarkan hukum sebagaimana telah dipertimbangkan sebelumnya maka tanah yang dihibahkan oleh M.Y. Panjaiatan kepada G.Sitorus beralih kepemilikannya setelah pemberi hibah M.Y.Panjaitan meninggal dunia, berdasarkan Akta Hibah No.32/1976 tanggal 29 Maret 1976 sah menurut hukum adalah milik G.Sitorus yang dalam dalam hal ini beralih kepemilikannya kepada ahli waris milik G.Sitorus karena pewarisan, maka 
tergugat $\mathrm{V}$ atau siapa saja yang mendapat hak atas tanah itu dari tergugat $\mathrm{V}$ harus dihukum untuk mengosongkan tanah terperkara dan menyerahkan tanah terperkara kepada penggugat dengan baik dalam keadaan kosong tanpa beban. Berdasarkan pertimbangan itu maka tuntutan penggugat pada petitum nomor 8 pada gugatan tersebut dapat dikabulkan.

Menimbang bahwa karena penggugat tidak dapat menunjukkan bukti secara konkrit penyebab kerugian materiel yang dideritanya, maka tuntutan ganti kerugian tersebut harus ditolak. Menimbang bahwa tuntutan ganti kerugian immateriell pada petitum nomor 10 pada gugatan tersebut cukup beralasan, oleh karena itu wajar tergugat I dan tergugat II dihukum untuk mengganti kerugian tersebut kepada penggugat sebesar Rp.100.000.000,00 (seratus juta rupiah). Menimbang bahwa Pengadilan tidak ada meletakkan sita (conservatoir beslaag), maka tuntutan penggugat pada petitum nomor 11 harus ditolak.

Berdasarkan seluruh pertimbangan tersebut, Majelis Hakim Pengadilan Tingkat Banding tidak sependapat dengan pertimbangan Majelis Hakim Pengadilan Tingkat Pertama dan Majelis Hakim Pengadilan Tingkat Banding berpendapat bahwa memori banding pembanding tersebut sangat beralasan berdasarkan hukum dan dapat membuktikan bahwa obyek sengketa adalah hak milik pembanding yang kebenarannya tidak dapat disangkal oleh pihak terbanding baik dalam kontra memori banding tersebut. Dan berdasarkan pertimbangan tersebut Majelis Hakim Pengadilan Tingkat Banding berpendapat putusan Pengadilan Negeri Simalungun No.55/Pdt.G/2014/PN-Sim tanggal 4 Februari 2015 tersebut tidak tepat dan harus dibatalkan serta Pengadilan
Tinggi akan mengadili kembali perkara ini.

\section{SIMPULAN}

Dari uraian dan pembahasan mengenai analisis yuridis penyelesaian sengketa hibah berdasarkan Putusan No.142/PDT/2015/PT-MDN, maka penulis dapat mengambil kesimpulan bahwa :

1. Dalam membuktikan suatu keabsahan Akta Hibah harus mempunyai kekuatan pembuktian lahiriah, formil dan materil, serta proses pembuatan Akta Hibah memenuhi unsur-unsur yang ditetapkan oleh Pasal 1868 KUH Perdata, yaitu:

a) Bentuk Akta ditentukan oleh Undang-Undang;

b) Akta dibuat oleh dan di hadapan pegawai-pegawai umum (pejabat umum) yang berkuasa (berwenang) dan

c) Akta dibuat di tempat di smana akta dibuatnya atau akta di buat dalam daerah kerja tertentu.

2. Pada dasarnya suatu hibah tidak dapat ditarik kembali akan tetapi dapat dibatalkan dengan berdasarkan pengecualian, yaitu:

a) KUH Perdata diantaranya adalah Pasal 1667 ayat (2), 1668, 1670, 1682, 1688 ayat (1, 2 dan 3);

b) Kompilasi Hukum Islam adalah Pasal 212;

c) Hukum Adat diantaranya adat Jawa Barat terutama di Desa Leuwi Liang dan Citeureup;

d) Kompilasi Hukum Ekonomi Syariah (KHES) diantaranya adalah Pasal 721, 722, 723.

3. Pertimbangan Hukum Majelis Hakim Pengadilan Tinggi Medan terhadap Putusan Pengadilan Negeri Simalungun 
No.55/Pdt.G/2014/PN-Sim

tentang penyelesaian sengketa hibah dalam perkara ini dinyatakan tidak tepat dan keliru karena memori banding pembanding tersebut sangat beralasan berdasarkan hukum dan dapat membuktikan bahwa obyek sengketa adalah hak milik pembanding yang kebenarannya tidak dapat disangkal oleh pihak terbanding dalam kontra memori banding tersebut. Selain itu, Amar Putusan Majelis Hakim Pengadilan Tinggi juga sudah menetapkan bahwa Akta Hibah No.32/1976 yang merupakan obyek sengketa adalah sah menurut hukum milik G.Sitorus yang telah dihibahkan M.Y.Panjaitan di hadapan H.Z.Sinaga selaku Camat Kecamatan Bandar Kabupaten Simalungun. Dan menetapkan Daud Sitorus sah secara hukum seorang ahli waris dari Almarhum G.Sitorus berdasarkan Surat Keterangan Ahli Waris No.2232/SK-AW/VI/2014 serta menghukum tergugat untuk mengosongkan tanah terperkara dengan baik dan kosong tanpa beban dan membayar ganti rugi merupakan bentuk pemenuhan keadilan serta kepastian hukum bagi para pihak dalam perkara ini.

\section{DAFTAR PUSTAKA}

\section{Buku-Buku}

HS, Salim, Pengantar Hukum Perdata Tertulis $(B W)$, Sinar Grafika, Jakarta :2014

Rofiq, Ahmad, Hukum Islam Di Indonesia, PT Raja Grafindo Persada, Jakarta: 2000
Samsaimun, Peraturan Jabatan PPAT, PRC (Pustaka Reka Cipta), Bandung:2018

Santoso, Urip.,Pejabat Pembuat Akta Tanah (perspektif regulasi, wewenang dan sifat akta),prenadamedia group, Jakarta: 2016

Soimin,Soedaryo, Hukum Orang dan Keluarga, Sinar Grafika, Jakarta:1992

Soekanto, Soerjono, Pengantar Penelitian Hukum, Universitas Indonesia, Jakarta:1986

Subekti, R, Aneka Perjanjian, PT. Citra Aditya Bakti, Bandung:1995

Suparman, Maman, Hukum Waris Perdata, Sinar Grafika, Jakarta: 2017

Sintha devi ria, Perkembangan Hukum Dagang di Indonesia, CV. Sentosa Deli Mandiri, Medan, 2020.

Wignjodipoero, Soerojo, Pengantar Dan Asas-Asas Hukum Adat, PT TOKO GUNUNG,Jakarta:1995

\section{Perundang-Undangan}

Kitab Undang-Undang Hukum Perdata Kitab Undang-Undang Hukum Dagang Kitab Undnag-undang Hukum Acara Perdata

\section{Jurnal}

Aji Surya Pratama, Abdul Halim Barkatullah, dan Rahmida Erliyani, Kedudukan Dana Asuransi Jiwa Dalam Relevansinya Dengan Pembagian Harta Warisan, Lambung Mangkurat Law Journal Vol. 4 No. 1 (2019)

ria sintha devi, Tinajaun Yuridis Perceraian Atas Perkawinan 
yang Tidak Tercatat Di Dinas

Kependudukan dan Pencatatan Sipil Kota Medan, Jurnal Retentum Vol. 1 No. 1 (2019):

Juli

, Tinjauan Yuridis Sita Jaminan dan Pemberesan Harta Milik Debitur Dalam Hal Terjadinya Kepailitan, Jurnal Ilmiah MAKSITEK Vol. 4 No. 4 (2019)

Suprima, Wardani Rizkianti, dan Khoirur Rizal Lutfi., Implikasi Hukum Penunjukan Ahli Waris Berdasarkan Klausul Asuransi Dalam Perspektif Hukum Waris Perdata, Jurnal Esensi Hukum Vol. 1 No.1 (2019)

Yasir Fauzi, Muhammad., Legislasi Hukum Kewarisan di Indonesia, Jurnal Pengembangan Masyarakat Islam Vol. 9 No. 2 (2016)

\section{Internet}

http://eprints.walisongo.ac.id/2072/4/72 111013 Bab3.pdf,diakses terakhir tanggal 18/05/2020,pukul 10.00

file:///C:/Users/Dell/Downloads/5316229-12698-1-10-

20171214.pdf,diakses terakhir 19/05/2020,pukul 14.00

http://etheses.uin-

malang.ac.id $/ 563 / 7 / 10220009 \% 20$

Bab\%203.pdfv,diakses terakhir tanggal23/05/2019, pukul 17.00 